\title{
Late stage Variscan magmatism in the Strzelin Massif (SW Poland): SHRIMP zircon ages of tonalite and Bt-Ms granite of the Gęsiniec intrusion
}

\author{
Teresa OBERC-DZIEDZIC and Ryszard KRYZA
}

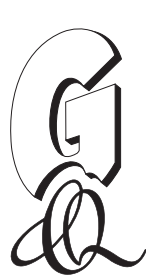

\begin{abstract}
Oberc-Dziedzic T. and Kryza R. (2012) - Late stage Variscan magmatism in the Strzelin Massif (SW Poland): SHRIMP zircon ages of tonalite and Bt-Ms granite of the Gęsiniec intrusion. Geol. Quart., 56 (2): 225-236, doi: 10.7306/gq.1017

The Gesiniec composite intrusion in the northern part of the Strzelin Massif (Fore-Sudetic Block, SW Poland) was formed in the course of three late Variscan magmatic episodes: tonalitic I, granodioritic, and tonalitic II/granitic. The age of the Gęsiniec tonalite, $295 \pm 3 \mathrm{Ma}$, is the same as that of another tonalite body in the southern part of the Strzelin Massif, the Kalinka tonalite. The younger biotite-muscovite (Bt-Ms) granite, in a dyke cutting the Gęsiniec tonalite, has an indistinguishable isotopic age of $295 \pm 5 \mathrm{Ma}$; it contains, however, inherited zircons with ages between $c a .1 .5 \mathrm{Ga}$ to $374 \mathrm{Ma}$, similar to zircon ages from surrounding gneisses. This suggests that the magmatic protolith of gneisses and the magma of the Bt-Ms granite could have come from similar sources, or that the magma of the Bt-Ms granite was contaminated by the gneisses. Both the tonalite and Bt-Ma granite represent a late stage of the granitoid magmatism in the eastern part of the Variscan orogen.
\end{abstract}

Teresa Oberc-Dziedzic and Ryszard Kryza, Institute of Geological Sciences, University of Wrocław, M. Borna 9, 50-204 Wrocław, Poland, e-mails: teresa.oberc-dziedzic@ing.uni.wroc.pl, ryszard.kryza@ing.uni.wroc.pl (received: Ocotober 5, 2011; accepted: January 11, 2012; first published online: May 6, 2012).

Key words: Strzelin Massif, Gęsiniec composite intrusion, Variscan granitoids, SHRIMP zircon ages.

\section{INTRODUCTION}

The Variscan orogenic belt in Central Europe abounds in granitoids that were formed in several magmatic events, between 370 and $250 \mathrm{Ma}$ (Finger et al., 1997) or 340 and $270 \mathrm{Ma}$ (Schaltegger, 1997). In the West and Central Sudetes, and in the adjoining Fore-Sudetic Block (NE part of the Bohemian Massif), the Variscan granitoid magmatism occurred between 330-305 Ma and 350-330 Ma, respectively (Mazur et al., 2007). The youngest Variscan granitoids, 324-295 Ma in age (Oberc-Dziedzic et al., 2010) are found in the Strzelin Massif in the eastern part of the Fore-Sudetic Block which, together with the East Sudetes, are correlated with Brunovistulicum (sensu Dudek, 1980; Finger et al., 1989).

The Variscan granitoids of the Strzelin Massif are different, in several aspects, from other Sudetic granitoids. They do not form large magmatic bodies, but numerous, small intrusions, composed of rocks petrographically variegated from quartz diorite to peraluminous granite. In many cases, petrographically similar rocks have different geochemical characteristics and ages. U-Pb SHRIMP ages reveal three distinct stages of the Carboniferous-early Permian granitoid magmatism: tonalitic I
- ca. $324 \mathrm{Ma}$, granodioritic - ca. $305 \mathrm{Ma}$, and tonalitic II/granitic - ca. $295 \mathrm{Ma}$ (Oberc-Dziedzic et al., 2010). In an earlier contribution (Oberc-Dziedzic et al., 2010), we provided evidence for two tonalitic stages: I - 324 Ma and II - 295 Ma in the southern part of the Strzelin Massif, and we showed petrographic and geochemical differences between tonalites of both stages. Here, in this paper, we present new SHRIMP zircon data from tonalite and biotite-muscovite (Bt-Ms) granite from the Gesiniec composite intrusion (northern part of the Strzelin Massif) and briefly discuss these within the context of the Variscan granitoid plutonism in the Fore-Sudetic Block, at the NE edge of the Bohemian Massif.

\section{GEOLOGICAL SETTING}

The Strzelin Massif (sensu Oberc-Dziedzic et al., 2010) is situated in the eastern part of the Fore-Sudetic Block, $35 \mathrm{~km}$ south of Wrocław (Fig. 1). Two structural units, separated by the Strzelin Thrust, are distinguished in this area: the lower unit (the footwall of the thrust) is composed of the rocks of the Strzelin Complex, and the upper unit (the hanging wall of the 


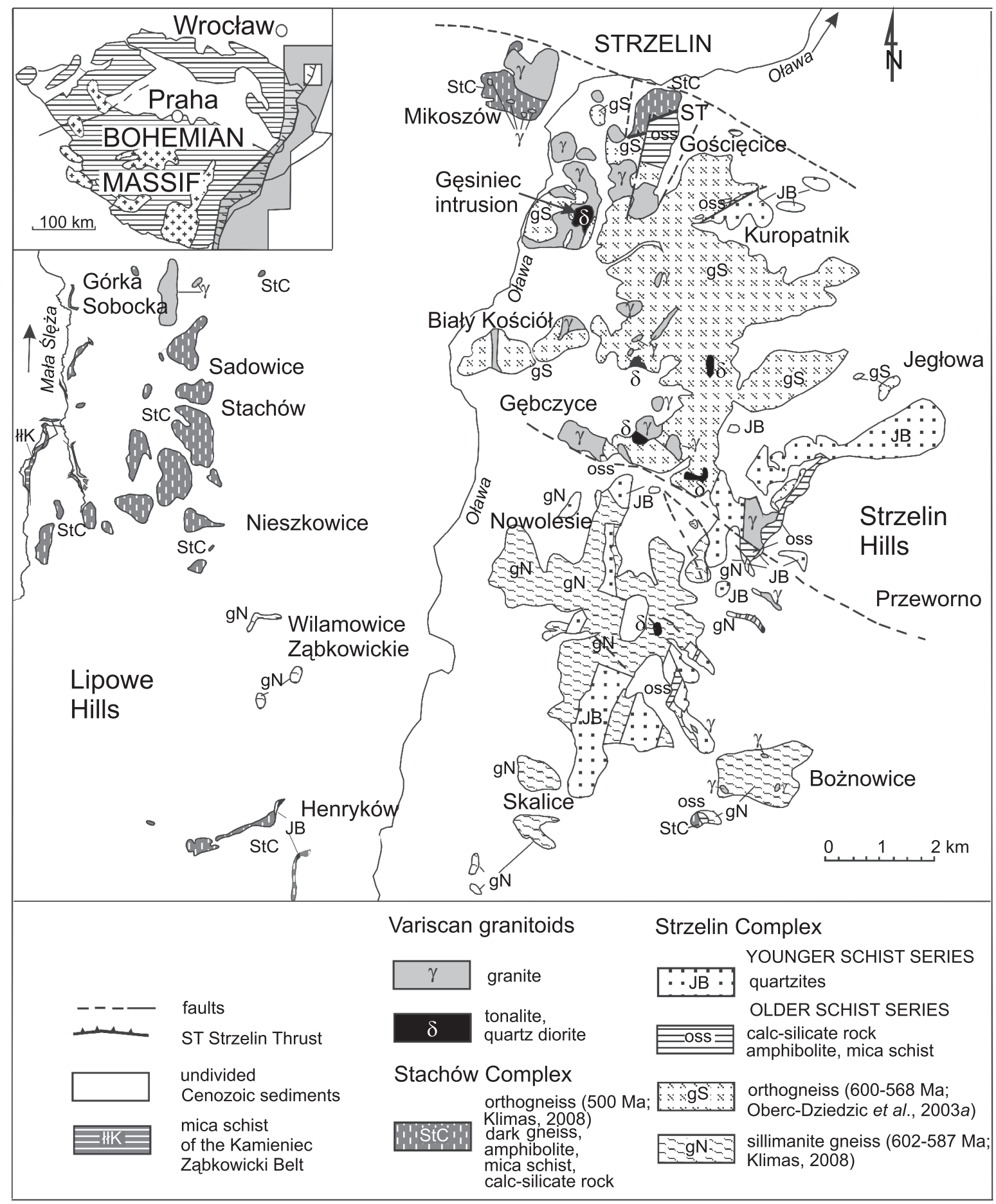

Fig. 1. Geological map of the Strzelin Massif

(compiled by Oberc-Dziedzic and Madej, 2002, based on Wójcik, 1968; Wroński, 1973; Badura, 1979; Oberc et al., 1988)

The Strzelin Thrust (ST in the northern part of the map) separates the Stachów and Strzelin complexes; inset map: Bohemian Massif and Moravo-Silesian Zone (grey-shaded); open rectangle shows the position of the Strzelin Massif;

Gęsiniec quarry location: N 5045’21', E $17^{\circ} 2^{\prime} 55^{\prime}$,

thrust), comprises the rocks of the Stachów Complex (Oberc-Dziedzic and Madej, 2002). The Strzelin Thrust is interpreted as the northern extension of the boundary between the East and West Sudetes (presently, the eastern part of the West Sudetes is defined as the Central Sudetes; Mazur et al., 2006), i.e. part of the tectonic boundary between the Brunovistulian and Moldanubian terranes in the NE part of the Bohemian Massif (Oberc-Dziedzic et al., 2005).

The Strzelin Complex is composed of Neoproterozoic gneisses: the Strzelin orthogneiss, typical of the northern part of the Strzelin Massif, with zircon ages of $600 \pm 7$ and $568 \pm 7 \mathrm{Ma}$ (the first interpreted as the magmatic age of the gneiss 
protholith, the second as the age of possible, later partial melting; Oberc-Dziedzic et al., 2003a), and the sillimanite Nowolesie gneiss, occurring in the southern part of the massif, with zircon ages of $602 \pm 7$ and $587 \pm 4 \mathrm{Ma}$ (Klimas, 2008) or $576 \pm 18 \mathrm{Ma}$ (Mazur et al., 2010). The Strzelin Complex comprises also, apart from the gneisses, the older schist series of Neoproterozoic or early Paleozoic(?) age, composed of amphibolites, mica schists, calc-silicate rocks and marbles, and the younger schist series (the Jegłowa Beds; Oberc, 1966) of quartzites, quartz-sericite schists and metaconglomerates. The Jegłowa Beds have been correlated with biostratigraphically documented Lower Devonian metaquartzites of the Jeseniki Mountains of the East Sudetes (Bederke, 1931; Oberc, 1966; Chlupač, 1975).

The Stachów Complex contains orthogneisses which yielded Early Ordovician ( 500 Ma) zircon ages (Oliver et al., 1993; Kröner and Mazur, 2003; Oberc-Dziedzic et al., 2003b; Klimas, 2008; Mazur et al., 2010) and dark-coloured, fine-grained gneiss. The intercalations of the dark gneiss with mica schists and amphibolites are interpreted as a Neoproterozoic or lower Paleozoic metasedimentary succession, representing the metamorphic envelope of the $\sim 500 \mathrm{Ma}$ old granitoid protolith of the orthogneisses (Oberc-Dziedzic and Madej, 2002).

The Strzelin and Stachów complexes underwent polyphase deformation and metamorphism that culminated during the Variscan orogeny (Oberc-Dziedzic et al., 2005, 2010).

The Strzelin Massif was intruded by four groups of Variscan granitoids:

- granodiorites ( $\sim 305 \mathrm{Ma}, \mathrm{U}-\mathrm{Pb}$ zircon SHRIMP method; Oberc-Dziedzic et al., 2010);

- tonalites and quartz diorites (I $\sim 324 \mathrm{Ma}$ and II $\sim 295 \mathrm{Ma}$, $\mathrm{U}-\mathrm{Pb}$ zircon SHRIMP method; Oberc-Dziedzic et al., 2010);

- medium- and fine-grained biotite granites;

- two-mica granites.

The ages of the latter two groups of rocks were estimated using various methods. The earlier Rb-Sr whole-rock studies (Oberc-Dziedzic et al., 1996; Oberc-Dziedzic and Pin, 2000) yielded relatively old dates of $347 \pm 12$ Ma for the biotite granites, and $330 \pm 6 \mathrm{Ma}$ for the two-mica granites. These dates have recently been questioned as too old, in the light of $\mathrm{Pb}$ evaporation zircon data for the biotite granite $(301 \pm 7 \mathrm{Ma}$; Turniak et al., 2006), and new SHRIMP zircon ages, combined with geological evidence, indicating that the two-mica granites are younger than the $\sim 295 \mathrm{Ma}$ tonalites (Oberc-Dziedzic et al., 2010).

\section{THE GĘSINIEC COMPOSITE INTRUSION}

The Gessiniec composite intrusion comprises the largest and best exposed tonalite body in the Strzelin Massif. Based on borehole data, this intrusion was interpreted as a stock with a flat apophysis (Fig. 2), and this interpretation has been confirmed in the course of the exploitation in the quarry. The tonalite body is cut by thin dykes of the fine-grained

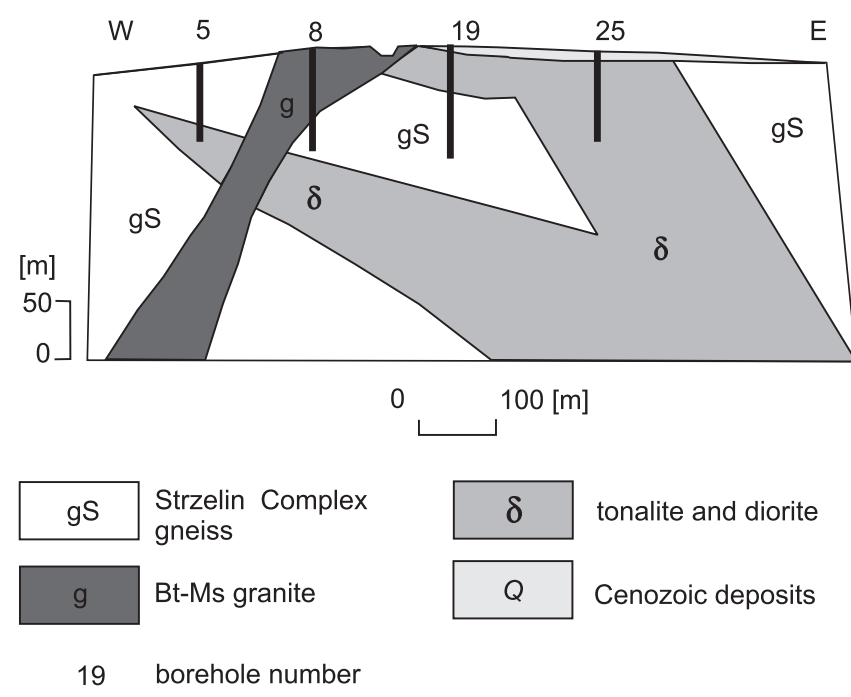

Fig. 2. Geological cross-section through the Gęsiniec intrusion, modified from Borek (1987)

granodiorite and by dykes of leucocratic, fine-grained Bt-Ms granite (Fig. 3), tens of centimetres to 15 metres thick. The envelope of the Gęsiniec intrusion is composed of the Strzelin Complex orthogneiss and amphibolite, the latter transformed into pyroxene hornfelses at the contact with the tonalite (Puziewicz and Oberc-Dziedzic, 1995; Oberc-Dziedzic, 2007).

The petrography of the Gęsiniec tonalites, diorites and granodiorites, sources of their magmas, processes of magma mixing, mingling, and fractional crystallisation recorded in plagioclases were studied by Pietranik et al. (2006), Pietranik and Waight (2008) and Pietranik and Koepke (2009). Pietranik and Waight (2008) defined several types of tonalites and diorites, based on field and analytical data. Here, in this paper, we describe only the main facies of the Gessiniec intrusion (Puziewicz and Oberc-Dziedzic, 1995; Oberc-Dziedzic, 2007). Our petrographic subdivision is simplified compared with that proposed by Pietranik and Waight (2008).

The marginal facies of the intrusion is formed of dark grey, very fine-grained quartz diorite (Table 1). This rock displays parallel alignment of plagioclase grains and the presence of biotite plates, up to $3 \mathrm{~mm}$ in size, surrounded by white quartz-plagioclase rims in places. The quartz diorite is brecciated and corroded by the tonalites.

The inner part of the intrusion consists of several facies of the tonalites. Some of these have been completely exploited. The tonalite facies differ in texture and proportion of the main components (Table 1 and Fig. 4). The shapes of apatite, titanite and plagioclase grains are highly variable. Plagioclase grains usually show corroded cores and a very complicated zoning which allow deciphering of processes in the tonalite magma before and after the emplacement (Pietranik and Waight, 2008). Dark minerals have random or parallel arrangement and they form clusters in places. The most common variety, forming the inner part of the intrusion, is pale grey, medium-grained tonalite, with uniformly distributed dark minerals. Locally, it shows an indistinct parallel texture. The medium-grained 

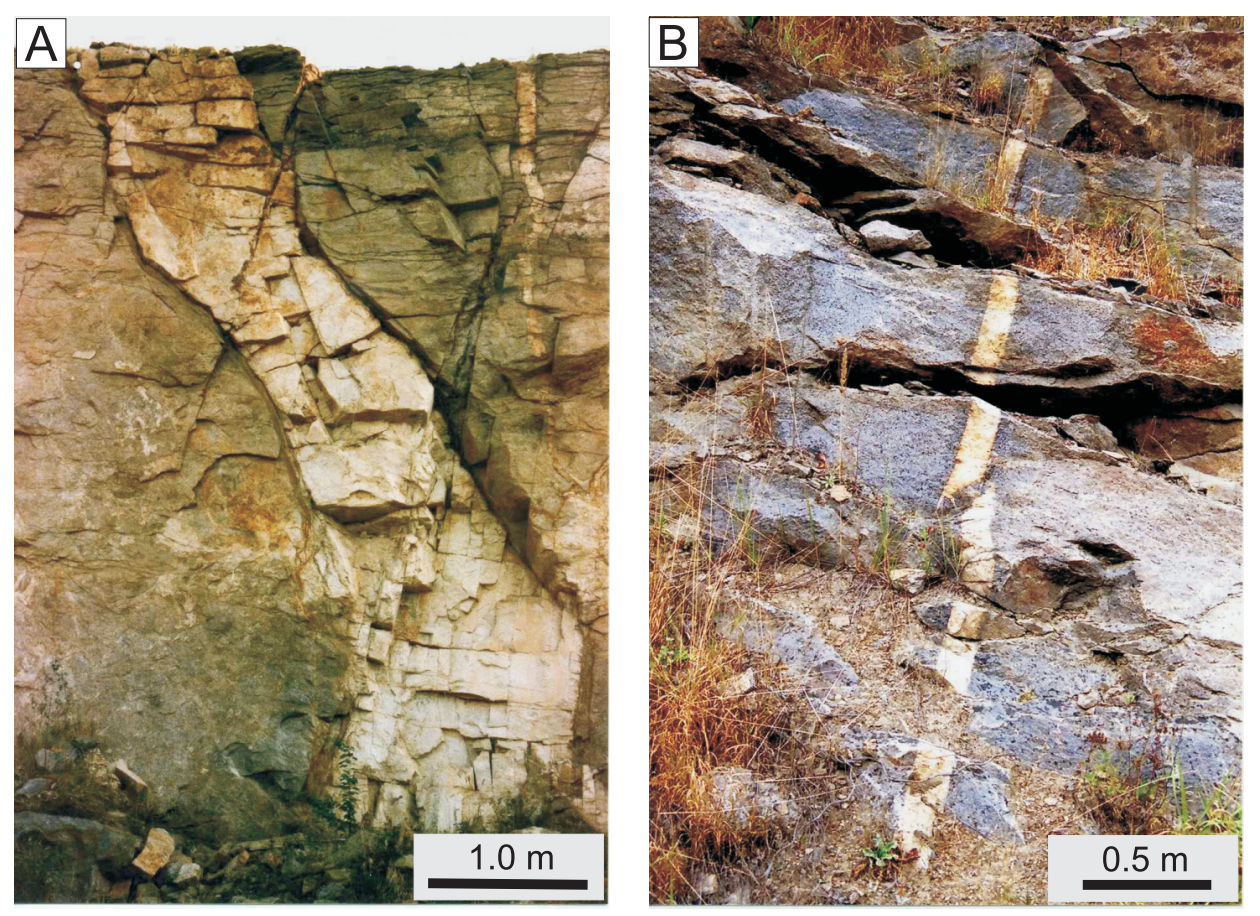

Fig. 3. Dykes of Bt-Ms granite in tonalite, Gęsiniec quarry (2006)

A - bent dyke, southern wall of the quarry; B - disrupted dyke, northern wall of the quarry

tonalite grades into dark, medium-grained tonalite, with irregularly distributed dark minerals concentrated into clusters or spots, up to $5 \mathrm{~mm}$ in size. The dark minerals are, locally, arranged into layers and schlieren. Another variety of the dark tonalite contains single plates of biotite, up to $5 \mathrm{~mm}$ large.

The pale grey, medium-grained and dark varieties of the tonalite can gradually change into pale tonalite. In the transition zones, the dark tonalites display a schlieren structure. The pale tonalite contains up to $1 \%$ microcline. Biotite is the only dark mineral. This type of tonalite also forms small dykes in the darker varieties.

Pietranik and Waight (2008) showed that different diorite-tonalite types are not related to each other by assimilation - fractional crystallisation processes but they probably evolved as separate magma batches.

The second magmatic injection in the Gęsiniec intrusion is represented by grey, fine-grained granodiorite (Puziewicz and Oberc-Dziedzic, 1995). This rock forms irregular streaks or dykes within the tonalites. Biotite and plagioclase composing

Mineral composition of the Gęsiniec tonalites and Bt-Ms granite

\begin{tabular}{|c|c|c|c|c|c|c|c|c|c|c|c|c|c|}
\hline \multirow[t]{2}{*}{ Minerals } & \multicolumn{3}{|c|}{$\begin{array}{l}\text { Dark, fine-grained } \\
\text { tonalite } \\
\text { T } 1\end{array}$} & \multicolumn{4}{|c|}{$\begin{array}{l}\text { Pale grey, medium-grained } \\
\text { tonalite } \\
\mathrm{T} 2 \\
\end{array}$} & \multicolumn{4}{|c|}{$\begin{array}{c}\text { Dark, medium-grained tonalite } \\
\text { T } 3\end{array}$} & \multirow{2}{*}{$\begin{array}{c}\text { Pale } \\
\text { tonalite } \\
\text { T } 4 \\
\text { GT8 }\end{array}$} & \multirow{2}{*}{$\begin{array}{c}\text { Bt-Ms } \\
\text { granite }\end{array}$} \\
\hline & GT1 & GT2 & GT3 & GT6 & GT9 & GT10 & GT13 & GT5 & GT7 & GT11 & GT12 & & \\
\hline Quartz & 14.3 & 12.2 & 9.4 & 16.9 & 23.8 & 16.9 & 18.6 & 18.7 & 20.2 & 12.8 & 20.8 & 34.4 & 34.8 \\
\hline Plagioclase & 48.5 & 52.0 & 47.3 & 58.2 & 51.0 & 46.8 & 51.5 & 47.8 & 40.1 & 50.2 & 32.3 & 50.4 & 36.9 \\
\hline Microcline & - & - & - & - & - & - & - & - & - & - & - & 0.9 & 26.3 \\
\hline Hornblende & 15.0 & 15.8 & 20 & 12.9 & 13.1 & 12.2 & 13.4 & 8.9 & 14.1 & 24.1 & 4.7 & - & - \\
\hline Biotite & 18.4 & 16.1 & 22.4 & 11.1 & 10.8 & 18.4 & 15.1 & 19.9 & 21.2 & 8.5 & 41.5 & 13.3 & 1.2 \\
\hline Titanite & 0.3 & 0.3 & - & - & - & 0.9 & - & - & 2.9 & - & - & - & - \\
\hline Apatite & 1.1 & 1.2 & - & 0.4 & 0.7 & 2.5 & 0.8 & 0.1 & - & 0.7 & 0.2 & 0.2 & - \\
\hline Opaque & 0.6 & 0.6 & 0.6 & 0.1 & 0.1 & 0.8 & 0.1 & 1.3 & 0.9 & 0.6 & 0.4 & - & - \\
\hline Chlorite & 1.8 & 1.8 & 0.3 & 0.4 & 0.5 & 1.5 & 0.5 & 3.3 & 0.6 & 2.6 & 0.1 & 0.8 & - \\
\hline Calcite & - & - & - & - & - & - & - & - & - & 0.5 & - & - & - \\
\hline Muscovite & - & - & - & - & - & - & - & - & - & 0.6 & - & - & 0.8 \\
\hline
\end{tabular}

- not found or below $0.1 \%$ 


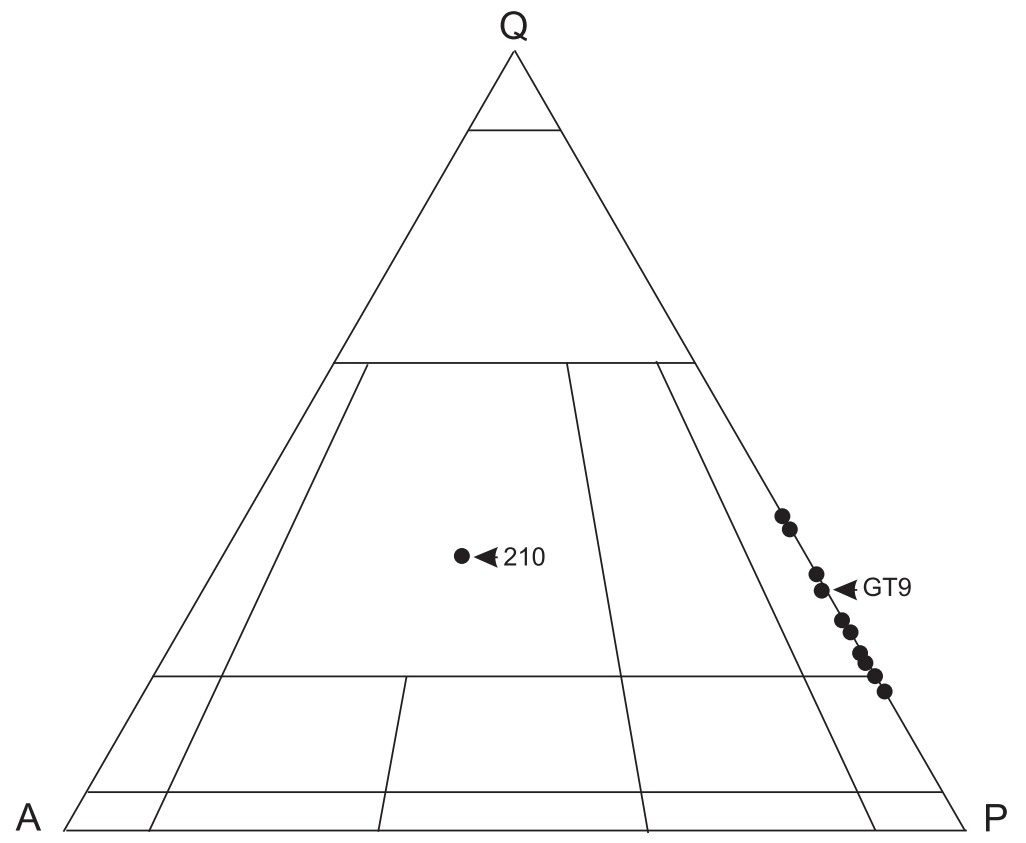

Fig. 4. Gęsiniec tonalites and Bt-Ms granite on a QAP diagram

GT9 and 210 - samples analysed by the SHRIMP method

the granodiorite are arranged parallel to the borders of the dykes. A detailed study of the granodiorite magma evolution was given by Pietranik et al. (2006).

The granodiorite is very rich in small, dark enclaves of mica schist, up to $3 \mathrm{~cm}$ in size. Gneissic enclaves are also very common. They are, occasionally, surrounded by thin quartz-feldspathic or biotite rims. Some enclaves are divided into parts of different orientation, suggesting their rotation in the magma.

The contacts of the granodiorite with the surrounding medium-grained tonalite are usually sharp. However, the granodiorite can also penetrate the tonalite. In that case, the contacts of the two rocks become irregular and small enclaves of tonalite appear in the granodiorite.

The third, youngest magmatic injection is represented by pale, fine-grained Bt-Ms granite. This granite forms a dyke about $15 \mathrm{~m}$ in thickness and several thinner dykes, 0.1-2 m thick (Fig. 3). The granite is composed of quartz, plagioclase, microcline, rare biotite and muscovite (Table 1 and Fig. 4), and contains also small pinite pseudomorphs after cordierite.

Seemingly, there is a close spatial relationship between the granodiorite and the Bt-Ms granite. The magmas of both rocks probably used the same channels during emplacement.

The Gęsiniec tonalites often display a parallel arrangement of dark minerals which define lineation and foliation. The magmatic foliation was followed by late-magmatic shear zones. In contrast to the tonalites, the Bt-Ms granite does not display any foliation or lineation (Oberc-Dziedzic, 1999).

\section{SHRIMP ZIRCON STUDY}

\section{METHODS}

The samples selected for the SHRIMP zircon study, tonalite GT9 and two-mica granite 210, each ca. 3-5 kg in weight, were crushed and the heavy mineral fraction $(0.06-0.25 \mathrm{~mm})$ separated using a standard procedure with heavy liquids and magnetic separation. Zircons were handpicked under a microscope, mounted in epoxy and polished. Transmitted and reflected light photomicrographs were made, along with CL images, in order to select grains and choose sites for analysis. U-Pb analyses were performed on the Sensitive High Resolution Ion Microprobe (SHRIMP II) at the All Russian Geological Research Institute (VSEGEI) in St. Petersburg, applying a secondary electron multiplier in peak-jumping mode, following the procedure described by Williams (1998) and Larionov et al. (2004). A primary beam of molecular oxygen was employed to bombard zircon in order to sputter secondary ions. The elliptical analytical spots had a size of $c a .27 \times 20 \mathrm{um}$, and the corresponding ion current was $c a .4 \mathrm{nA}$. The sputtered secondary ions were extracted at $10 \mathrm{kV}$. The $80 \mathrm{~mm}$ wide slit of the secondary ion source, in combination with a 100 um multiplier slit, allowed mass-resolution of M/AM $>5000$ ( $1 \%$ valley) so that all the possible isobaric interferences were resolved. One-minute rastering over a rectangular area of ca. $60 \times 50$ um was employed before each analysis in order to remove the gold coating and possible surface common $\mathrm{Pb}$ contamination.

The following ion species were measured in sequence: ${ }^{196}\left(\mathrm{Zr}_{2} \mathrm{O}\right)-{ }^{204} \mathrm{~Pb}$-background (ca. $\left.204 \mathrm{AMU}\right)-{ }^{206} \mathrm{~Pb}^{207} \mathrm{~Pb}-{ }^{208} \mathrm{~Pb}-$ ${ }^{238} \mathrm{U}^{248}{ }^{24 h o-}{ }^{254} \mathrm{UO}$ with integration time ranging from 2 to 20 seconds. Four cycles for each spot analysed were acquired. Each fifth measurement was carried out on the zircon $\mathrm{Pb} / \mathrm{U}$ standard TEMORA (Black et al., 2003) with an accepted ${ }^{206} \mathrm{~Pb} /{ }^{238} \mathrm{U}$ age of $416.75 \pm 0.24 \mathrm{Ma}$. The 91500 zircon, with a $\mathrm{U}$ concentration of $81.2 \mathrm{ppm}$ and $\mathrm{a}{ }^{206} \mathrm{~Pb} /{ }^{238} \mathrm{U}$ age of 1062.4 $\pm 0.4 \mathrm{Ma}$ (Wiedenbeck et al., 1995), was applied as a "U-concentration" standard. The results collected were then processed with the SQUID v1.12 (Ludwig, 2005a) and ISOPLOT/Ex 3.22 (Ludwig, 2005b) software, using the decay constants of Steiger and Jäger (1977). The common lead correction was done using measured ${ }^{204} \mathrm{~Pb}$ according to the model of Stacey and Kramers (1975). The results of the zircon analyses are shown in Tables 2 and 3, and Figures 5-8.

\section{SAMPLE GT9 (TONALITE)}

Sample GT9 represents the pale grey, medium-grained tonalite, the most homogeneous facies of the Gesiniec tonalite 
SHRIMP data for zircons from the Gąsiniec tonalite (Gąsiniec quarry, sample GT9)

\begin{tabular}{|c|c|c|c|c|c|c|c|c|c|c|c|c|c|c|c|c|c|c|c|c|c|}
\hline Spot & $\begin{array}{c}{ }^{206} \mathrm{~Pb}_{\mathrm{c}} \\
{[\%]}\end{array}$ & $\left.\begin{array}{c}\mathrm{U} \\
{[\mathrm{ppm}]}\end{array}\right]$ & $\begin{array}{c}\text { Th } \\
{[\mathrm{ppm}]}\end{array}$ & ${ }^{232} \mathrm{Th} /{ }^{238} \mathrm{U}$ & $\begin{array}{l}{ }^{206} \mathrm{~Pb}^{*} \\
{[\mathrm{ppm}]}\end{array}$ & $\begin{array}{r}{ }^{206} \mathrm{Pt} \\
\mathrm{A}\end{array}$ & & ${ }^{207} \mathrm{~Pb}$ & & $\begin{array}{c}\text { Discordant } \\
{[\%]}\end{array}$ & $\begin{array}{c}\text { Total } \\
{ }^{238} \mathrm{U} /{ }^{206} \mathrm{~Pb}\end{array}$ & $\begin{array}{c} \pm \\
{[\%]}\end{array}$ & $\begin{array}{c}\text { Total } \\
{ }^{207} \mathrm{~Pb} /{ }^{206} \mathrm{~Pb}\end{array}$ & $\begin{array}{c} \pm \\
{[\%]}\end{array}$ & $\begin{array}{c}(1) \\
{ }^{207} \mathrm{~Pb}^{*} / \\
{ }^{206} \mathrm{~Pb}^{*}\end{array}$ & $\begin{array}{c} \pm \\
{[\%]}\end{array}$ & ${ }^{207} \mathrm{~Pb}^{(1)}{ }^{235} \mathrm{U}$ & $\begin{array}{c} \pm \\
{[\%]}\end{array}$ & $\begin{array}{c}(1) \\
{ }^{206} \mathrm{~Pb}^{*} /{ }^{238} \mathrm{U}\end{array}$ & $\begin{array}{c} \pm \\
{[\%]}\end{array}$ & $\begin{array}{l}\text { err. } \\
\text { corr. }\end{array}$ \\
\hline GT9 .1.1 & 0.59 & 348 & 231 & 0.69 & 14.6 & 304.8 & \pm 6.9 & 394 & \pm 180 & 29 & 20.53 & 2.3 & 0.0593 & 4.0 & 0.0545 & 8.1 & 0.364 & 8.4 & 0.048 & 2.3 & 0.275 \\
\hline GT9 2.1 & 1.46 & 238 & 126 & 0.55 & 9.8 & 298.0 & \pm 8.3 & 114 & \pm 590 & -62 & 20.82 & 2.4 & 0.0599 & 4.9 & 0.0480 & 25.0 & 0.315 & 25.0 & 0.047 & 2.9 & 0.114 \\
\hline GT9 3.1 & 1.04 & 408 & 208 & 0.53 & 16.3 & 290.0 & \pm 6.8 & 209 & \pm 220 & -28 & 21.51 & 2.3 & 0.0586 & 3.6 & 0.0503 & 9.4 & 0.319 & 9.7 & 0.046 & 2.4 & 0.248 \\
\hline GT9 4.1 & 1.61 & 211 & 97 & 0.48 & 8.5 & 289.4 & \pm 7.5 & 425 & \pm 340 & 47 & 21.41 & 2.4 & 0.0684 & 4.6 & 0.0553 & 15.0 & 0.350 & 15.0 & 0.045 & 2.6 & 0.173 \\
\hline GT9 5.1 & 0.70 & 771 & 715 & 0.96 & 33.0 & 311.7 & \pm 6.1 & 78 & \pm 210 & -75 & 20.04 & 1.9 & 0.0531 & 2.5 & 0.0476 & 8.8 & 0.325 & 9.0 & 0.049 & 2.0 & 0.222 \\
\hline GT9 6.1 & 0.27 & 815 & 489 & 0.62 & 32.5 & 291.9 & \pm 5.3 & 241 & \pm 62 & -17 & 21.53 & 1.9 & 0.0532 & 1.8 & 0.0510 & 2.7 & 0.326 & 3.3 & 0.046 & 1.9 & 0.570 \\
\hline GT9 7.1 & 0.38 & 459 & 40 & 0.09 & 18.0 & 286.1 & \pm 5.4 & 247 & \pm 99 & -14 & 21.95 & 1.9 & 0.0542 & 2.4 & 0.0511 & 4.3 & 0.320 & 4.7 & 0.045 & 1.9 & 0.413 \\
\hline GT9 8.1 & 0.30 & 291 & 147 & 0.52 & 11.5 & 288.1 & \pm 5.7 & 259 & \pm 130 & -10 & 21.81 & 2.0 & 0.0538 & 3.0 & 0.0514 & 5.7 & 0.324 & 6.0 & 0.045 & 2.0 & 0.337 \\
\hline GT9 9.1 & 0.47 & 652 & 88 & 0.14 & 24.6 & 276.0 & \pm 5.1 & 226 & \pm 93 & -18 & 22.75 & 1.9 & 0.0544 & 2.0 & 0.0507 & 4.0 & 0.306 & 4.4 & 0.043 & 1.9 & 0.428 \\
\hline GT9 10.1 & 0.04 & 237 & 243 & 1.06 & 9.4 & 290.2 & \pm 5.9 & 301 & \pm 79 & 4 & 21.71 & 2.1 & 0.0526 & 3.4 & 0.0524 & 3.5 & 0.332 & 4.0 & 0.046 & 2.1 & 0.511 \\
\hline GT9 11.1 & 0.24 & 355 & 166 & 0.48 & 14.2 & 291.5 & \pm 5.6 & 186 & \pm 110 & -36 & 21.57 & 2.0 & 0.0517 & 2.8 & 0.0498 & 4.8 & 0.318 & 5.2 & 0.046 & 2.0 & 0.384 \\
\hline GT9 11.2 & 0.12 & 2731 & 206 & 0.08 & 109.0 & 292.2 & \pm 5.1 & 273 & \pm 37 & -7 & 21.54 & 1.8 & 0.0527 & 1.1 & 0.0517 & 1.6 & 0.331 & 2.4 & 0.046 & 1.8 & 0.740 \\
\hline GT9 12.1 & 0.37 & 1355 & 114 & 0.09 & 50.4 & 272.2 & \pm 5.0 & 258 & \pm 77 & -5 & 23.09 & 1.9 & 0.0544 & 1.4 & 0.0514 & 3.4 & 0.306 & 3.9 & 0.043 & 1.9 & 0.487 \\
\hline GT9 12.2 & 0.99 & 221 & 104 & 0.48 & 9.04 & 296.5 & \pm 6.1 & 256 & \pm 150 & -14 & 21.03 & 2.1 & 0.0593 & 3.2 & 0.0513 & 6.7 & 0.333 & 7.0 & 0.047 & 2.1 & 0.298 \\
\hline GT9 13.1 & 0.13 & 683 & 606 & 0.92 & 28.2 & 301.9 & \pm 5.9 & 417 & \pm 71 & 38 & 20.83 & 2.0 & 0.0562 & 2.9 & 0.0551 & 3.2 & 0.364 & 3.8 & 0.048 & 2.0 & 0.532 \\
\hline GT9 14.1 & 0.31 & 909 & 54 & 0.06 & 37.2 & 298.9 & \pm 5.4 & 292 & \pm 73 & -2 & 21.01 & 1.8 & 0.0547 & 1.6 & 0.0522 & 3.2 & 0.341 & 3.7 & 0.047 & 1.9 & 0.499 \\
\hline GT9 15.1 & 1.08 & 185 & 196 & 1.09 & 7.8 & 305.2 & \pm 6.5 & 148 & \pm 260 & -51 & 20.40 & 2.1 & 0.0576 & 3.4 & 0.0490 & 11.0 & 0.328 & 11.0 & 0.048 & 2.2 & 0.195 \\
\hline GT9 16.1 & 0.61 & 437 & 504 & 1.19 & 18.2 & 303.7 & \pm 6.0 & 160 & \pm 140 & -47 & 20.60 & 2.0 & 0.0541 & 2.9 & 0.0493 & 5.9 & 0.328 & 6.2 & 0.048 & 2.0 & 0.323 \\
\hline GT9 17.1 & 0.84 & 509 & 474 & 0.96 & 19.9 & 284.7 & \pm 5.7 & 106 & \pm 200 & -63 & 21.96 & 2.0 & 0.0548 & 2.8 & 0.0481 & 8.7 & 0.300 & 8.9 & 0.045 & 2.0 & 0.229 \\
\hline GT9 18.1 & 1.13 & 522 & 531 & 1.05 & 21.0 & 291.6 & \pm 6.3 & -113 & \pm 290 & -139 & 21.36 & 2.1 & 0.0529 & 3.2 & 0.0440 & 12.0 & 0.281 & 12.0 & 0.046 & 2.2 & 0.185 \\
\hline
\end{tabular}

Errors are $1 \sigma ; \mathrm{Pb}_{\mathrm{c}}$ and $\mathrm{Pb}^{*}$ indicate the common and radiogenic portions, respectively; error in standard calibration was $0.78 \% ;(1)-$ common $\mathrm{Pb}$ corrected using measured ${ }^{204} \mathrm{~Pb}$ 
SHRIMP data for zircons from the Bt-Ms granite (Gęsiniec quarry, sample 210)

\begin{tabular}{|c|c|c|c|c|c|c|c|c|c|c|c|c|c|c|c|c|c|c|c|c|c|}
\hline Spot & $\begin{array}{c}{ }^{206} \mathrm{~Pb}_{\mathrm{c}} \\
{[\%]}\end{array}$ & $\begin{array}{c}\mathrm{U} \\
{[\mathrm{ppm}]}\end{array}$ & $\begin{array}{c}\text { Th } \\
{[\mathrm{ppm}]}\end{array}$ & $\begin{array}{l}{ }^{232} \mathrm{Th} \\
\rho^{238} \mathrm{U}\end{array}$ & $\begin{array}{l}{ }^{206} \mathrm{~Pb}^{*} \\
{[\mathrm{ppm}]}\end{array}$ & $\begin{array}{r}{ }^{206} \mathrm{~Pb} / \\
\mathrm{Ag}\end{array}$ & & ${ }^{207} \mathrm{~Pb}$ & & $\begin{array}{l}\text { Discor- } \\
\text { dant [\%] }\end{array}$ & $\begin{array}{l}\text { Total } \\
{ }^{238} \mathrm{U} \\
{ }^{206} \mathrm{~Pb}\end{array}$ & $\begin{array}{c} \pm \\
{[\%]}\end{array}$ & $\begin{array}{l}\text { Total } \\
{ }^{207} \mathrm{~Pb} \\
{ }^{206} \mathrm{~Pb}\end{array}$ & $\begin{array}{c} \pm \\
{[\%]}\end{array}$ & 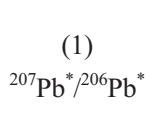 & $\begin{array}{c} \pm \\
{[\%]}\end{array}$ & ${ }^{207} \mathrm{~Pb}^{*} /{ }^{235} \mathrm{U}$ & $\begin{array}{c} \pm \\
{[\%]}\end{array}$ & $\begin{array}{c}(1) \\
{ }^{206} \mathrm{~Pb}^{*} /{ }^{238} \mathrm{U}\end{array}$ & $\begin{array}{c} \pm \\
{[\%]}\end{array}$ & $\begin{array}{l}\text { err. } \\
\text { corr. }\end{array}$ \\
\hline 2101.1 & 0.20 & 830 & 424 & 0.53 & 35.0 & 308.7 & \pm 6.2 & 304 & \pm 95 & -1 & 20.34 & 2.0 & 0.0540 & 2.8 & 0.0524 & 4.2 & 0.355 & 4.7 & 0.049 & 2.0 & 0.439 \\
\hline 2101.2 & 0.34 & 944 & 52 & 0.06 & 48.6 & 373.9 & \pm 6.7 & 503 & \pm 55 & 35 & 16.69 & 1.8 & 0.0601 & 1.5 & 0.0573 & 2.5 & 0.472 & 3.1 & 0.059 & 1.8 & 0.592 \\
\hline 2102.1 & 1.36 & 1539 & 1198 & 0.80 & 116.0 & 534.0 & \pm 10.0 & 637 & \pm 110 & 19 & 11.41 & 2.0 & 0.0721 & 1.5 & 0.0610 & 4.9 & 0.726 & 5.3 & 0.086 & 2.0 & 0.385 \\
\hline 2102.2 & 7.39 & 2920 & 2984 & 1.06 & 122.0 & 282.1 & \pm 5.6 & 446 & \pm 230 & 58 & 20.64 & 1.9 & 0.1157 & 1.8 & 0.0559 & 10.0 & 0.344 & 11.0 & 0.044 & 2.0 & 0.190 \\
\hline 2103.1 & 0.30 & 1397 & 518 & 0.38 & 53.8 & 281.7 & \pm 5.4 & 262 & \pm 97 & -7 & 22.32 & 2.0 & 0.0539 & 2.0 & 0.0515 & 4.2 & 0.317 & 4.6 & 0.044 & 2.0 & 0.424 \\
\hline 2104.1 & 0.30 & 2573 & 433 & 0.17 & 108.0 & 306.4 & \pm 5.5 & 370 & \pm 63 & 21 & 20.48 & 1.8 & 0.0564 & 1.3 & 0.0540 & 2.8 & 0.362 & 3.3 & 0.048 & 1.8 & 0.549 \\
\hline 2105.1 & 0.00 & 1138 & 35 & 0.03 & 96.7 & $\begin{array}{l}608.0 \\
\end{array}$ & \pm 11.0 & 575 & \pm 33 & -5 & 10.11 & 1.9 & 0.0592 & 1.5 & 0.0592 & 1.5 & 0.808 & 2.4 & 0.098 & 1.9 & 0.780 \\
\hline 2106.1 & 0.07 & 471 & 133 & 0.29 & 67.1 & 990.0 & \pm 17.0 & 1252 & \pm 24 & 27 & 6.02 & 1.9 & 0.0829 & 1.1 & 0.0823 & 1.2 & 1.883 & 2.2 & 0.165 & 1.9 & 0.840 \\
\hline 2106.2 & 0.08 & 428 & 237 & 0.57 & 101.0 & 1565.0 & \pm 26.0 & 1478 & \pm 19 & -6 & 3.64 & 1.9 & 0.0932 & 0.9 & 0.0925 & 10.0 & 3.504 & 2.1 & 0.274 & 1.9 & 0.881 \\
\hline 2107.1 & 0.06 & 2114 & 638 & 0.31 & 86.0 & 297.9 & \pm 5.3 & 322 & \pm 35 & 8 & 21.13 & 1.8 & 0.0533 & 1.2 & 0.0528 & 1.5 & 0.345 & 2.4 & 0.047 & 1.8 & 0.770 \\
\hline 2106.3 & 0.12 & 1585 & 68 & 0.04 & 104.0 & $\begin{array}{l}474.3 \\
\end{array}$ & \pm 8.7 & 614 & \pm 38 & 29 & 13.08 & 1.9 & 0.0613 & 1.3 & 0.0603 & 1.8 & 0.635 & 2.6 & 0.076 & 1.9 & 0.730 \\
\hline 2108.1 & 0.35 & 706 & 73 & 0.11 & 28.9 & 298.7 & \pm 5.7 & 266 & \pm 87 & -11 & 21.01 & 1.9 & 0.0544 & 2.4 & 0.0516 & 3.8 & 0.337 & 4.3 & 0.047 & 1.9 & 0.458 \\
\hline 2109.1 & 0.60 & 407 & 24 & 0.06 & 28.6 & $\begin{array}{l}503.7 \\
\end{array}$ & \pm 9.5 & 449 & \pm 100 & -11 & 12.23 & 1.9 & 0.0608 & 2.2 & 0.0559 & 4.6 & 0.627 & 5.0 & 0.081 & 2.0 & 0.393 \\
\hline 21010.1 & 0.77 & 614 & 121 & 0.20 & 23.8 & 282.2 & \pm 5.3 & 267 & \pm 120 & -6 & 22.17 & 1.9 & 0.0578 & 2.1 & 0.0516 & 5.2 & 0.318 & 5.5 & 0.044 & 1.9 & 0.349 \\
\hline 21011.1 & - & 623 & 182 & 0.30 & 25.5 & 300.3 & \pm 5.7 & 355 & \pm 61 & 18 & 20.98 & 2.0 & 0.0533 & 2.7 & 0.0536 & 2.7 & 0.352 & 3.3 & 0.047 & 2.0 & 0.588 \\
\hline 21012.1 & 6.78 & 543 & 213 & 0.41 & 16.6 & 210.1 & \pm 4.8 & 473 & \pm 480 & 125 & 28.06 & 1.9 & 0.1116 & 6.2 & 0.0570 & 21.0 & 0.258 & 22.0 & 0.033 & 2.3 & 0.107 \\
\hline 21013.1 & 2.48 & 1182 & 179 & 0.16 & 66.9 & 401.1 & \pm 7.2 & 460 & \pm 110 & 15 & 15.18 & 1.8 & 0.0763 & 1.6 & 0.0562 & 5.2 & 0.497 & 5.5 & 0.064 & 1.9 & 0.337 \\
\hline 21013.2 & 4.36 & 6565 & 2423 & 0.38 & 246.0 & 263.2 & \pm 4.9 & 328 & \pm 190 & 24 & 22.92 & 1.8 & 0.0881 & 0.59 & 0.0530 & 8.5 & 0.304 & 8.7 & 0.041 & 1.9 & 0.217 \\
\hline 21014.1 & 0.44 & 969 & 65 & 0.07 & $\begin{array}{l}39.9 \\
\end{array}$ & 300.6 & \pm 5.5 & 199 & \pm 82 & -34 & 20.85 & 1.9 & 0.0536 & 1.9 & 0.0501 & 3.5 & 0.330 & 4.0 & 0.047 & 1.9 & 0.468 \\
\hline 21015.1 & 0.31 & 1817 & 949 & 0.54 & 72.5 & 291.7 & \pm 5.5 & 212 & \pm 110 & -27 & 21.53 & 1.9 & 0.0527 & 1.7 & 0.0504 & 4.9 & 0.321 & 5.3 & 0.0463 & 1.9 & 0.364 \\
\hline
\end{tabular}

For explanations see Table 2 


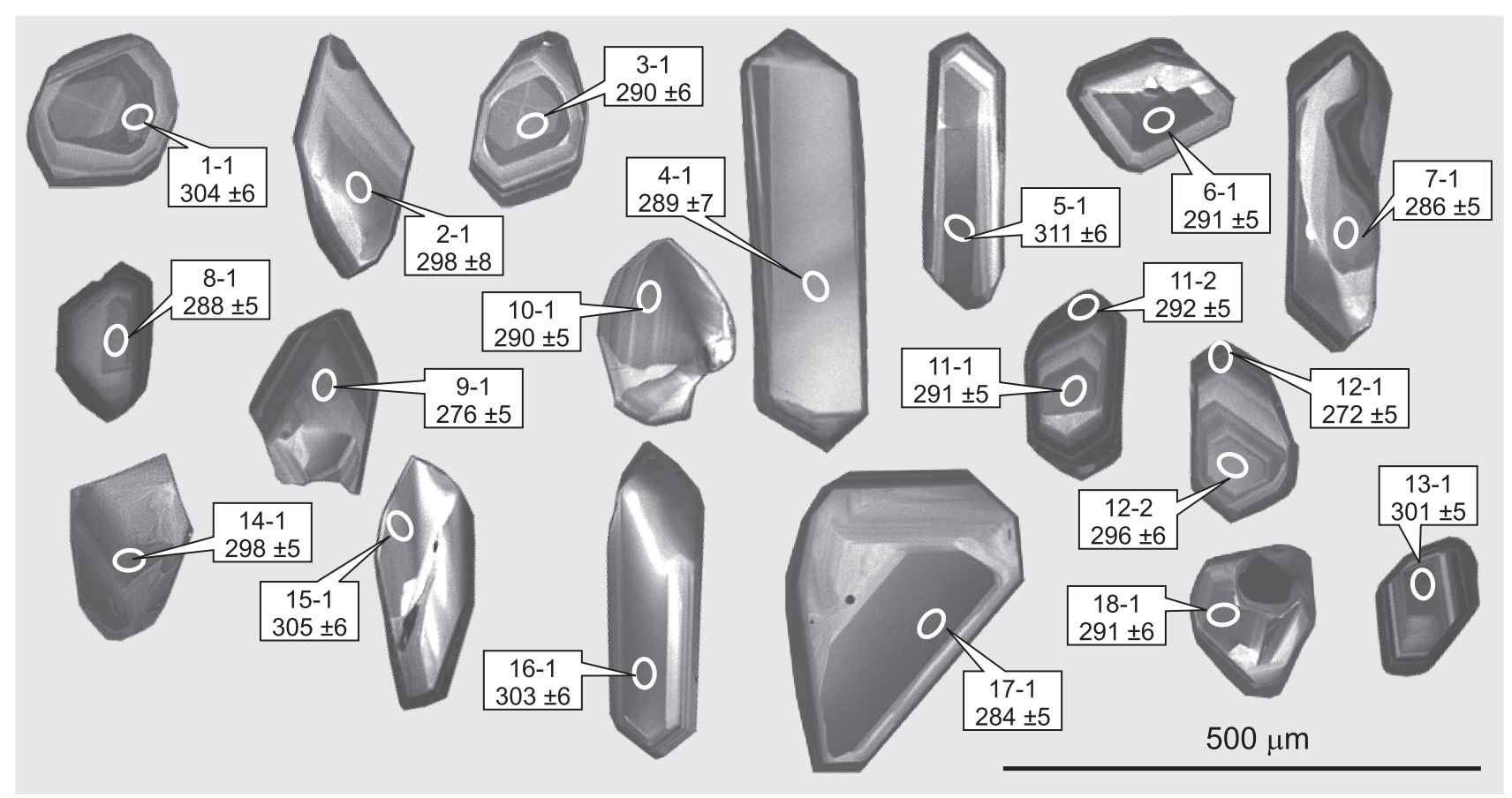

Fig. 5. Cathodoluminescence images of zircons analysed from tonalite GT9

Symbols of analytical points correspond to those in Table $2 ;{ }^{206} \mathrm{~Pb} /{ }^{238} \mathrm{U}$ ages and one $-\sigma$ errors (rounded to integers) are given

(Table 1 and Fig. 4) showing a poorly visible parallel arrangement of dark minerals. The rock corresponds to leucocratic, medium-grained quartz diorite in Pietranik and Waight (2008) classification. The GT9 tonalite is composed of euhedral, zoned grains of plagioclase $\left(\mathrm{An}_{60-15}\right)$ surrounded by anhedral grains of quartz showing a wavy extinction. Dark minerals are represented by biotite and green hornblende occurring as individual grains or aggregates. Apatite and zircon are common accessories.

The zircons of this sample (Fig. 5) are relatively large, euhedral, mostly short- and subordinately normal-prismatic. The majority of the crystals display a regular "euhedral" zonal pattern: CL-dark central parts overgrown by a bright regularly zoned mantle, and dark and usually thin outer rims. Longer crystals have usually less distinct internal structure.

Twenty points in eighteen zircon grains in tonalite sample GT9 were analysed by SHRIMP. Practically, all the points analysed belong to one homogeneous group, with only two analyses yielding somewhat younger ${ }^{206} \mathrm{~Pb} /{ }^{238} \mathrm{U}$ ages: 9.1 (276 $\pm 5 \mathrm{Ma})$ and 12.1 (272 $\pm 5 \mathrm{Ma})$. The Concordia age for all the points is $291.9 \pm 3.5 \mathrm{Ma}$, and with the two youngest points excluded $-294.7 \pm 2.8 \mathrm{Ma}$ (Fig. 6). All the analyses confirm the homogeneity of the zircon population: $\mathrm{Pb}_{\mathrm{c}}$ values are mostly below $1 \%$ (maximum value $1.46 \%$ ). $\mathrm{U}$, Th and $\mathrm{Pb}$ concentrations are also similar in most of the grains, with two exceptions (11.2 and 12.1) which are much richer in $U$ (Table 2). The ${ }^{232} \mathrm{Th} /{ }^{238} \mathrm{U}$ ratios vary from low (0.06) to fairly high (1.19), with rather even dispersion over the whole range; the lowest values may correspond to late-magmatic crystallisation. Discordance varies from -75 (one extreme value -139 in grain 18.1 ) to +47 , with several points of considerably lower values.
Summing up, the zircon population in the tonalite is homogeneous and represents a magmatic crystallisation stage at $c a .295$ $\pm 3 \mathrm{Ma}$. The strong CL zonation is not reflected in age variation.

\section{SAMPLE 210 (TWO-MICA GRANITE)}

Sample 210 was taken from a Bt-Ms granite dyke, 15 metres thick, situated in the eastern part of the Gęsiniec quarry. It represents a pale, fine-grained granite with rare, dispersed, rounded or square pinite pseudomorphs after cordierite. The granite is composed of euhedral or subhedral grains of plagioclase $\left(\mathrm{An}_{24-6}\right)$ with scarce muscovite inclusions, and anhedral grains of microcline and quartz. Brown biotite and muscovite form sparsely distributed small plates. Accessory zircon is not abundant.

The zircon grains in this sample have various morphologies and other different features (Fig. 7). Most of them are euhedral, normal-prismatic, with a distinct internal recurrent zonation, well visible in CL images (grains 1.1, 3.1, 4.1, 5.1, 6.1, 9.1, 13.1 and 14.1). Usually CL-bright interiors have thin CL-dark euhedral overgrowths. A few of the grains analysed have rather distinct cores (e.g., 2.1 and 10.1) and oval inclusions (11.1). Several crystals are CL-dark and less clearly structured (7.1, $8.1,15.1)$, and a few are broken $(7.1,12.1)$.

Twenty points in 15 zircon crystals were analysed by SHRIMP. Eight points yielded relatively old ages, between $373 \mathrm{Ma}$ and $1.5 \mathrm{Ga}$, and were interpreted as inheritance. The core of one grain (6.2) displays a Mesoproterozoic, slightly discordant $(\mathrm{D}=-6 \%){ }^{207} \mathrm{~Pb} /{ }^{206} \mathrm{~Pb}$ age of $1478 \pm 19 \mathrm{Ma}$. Characteristically, its mantle (6.1) is $990 \pm 17 \mathrm{Ma}$ old, and its rim (6.3) 


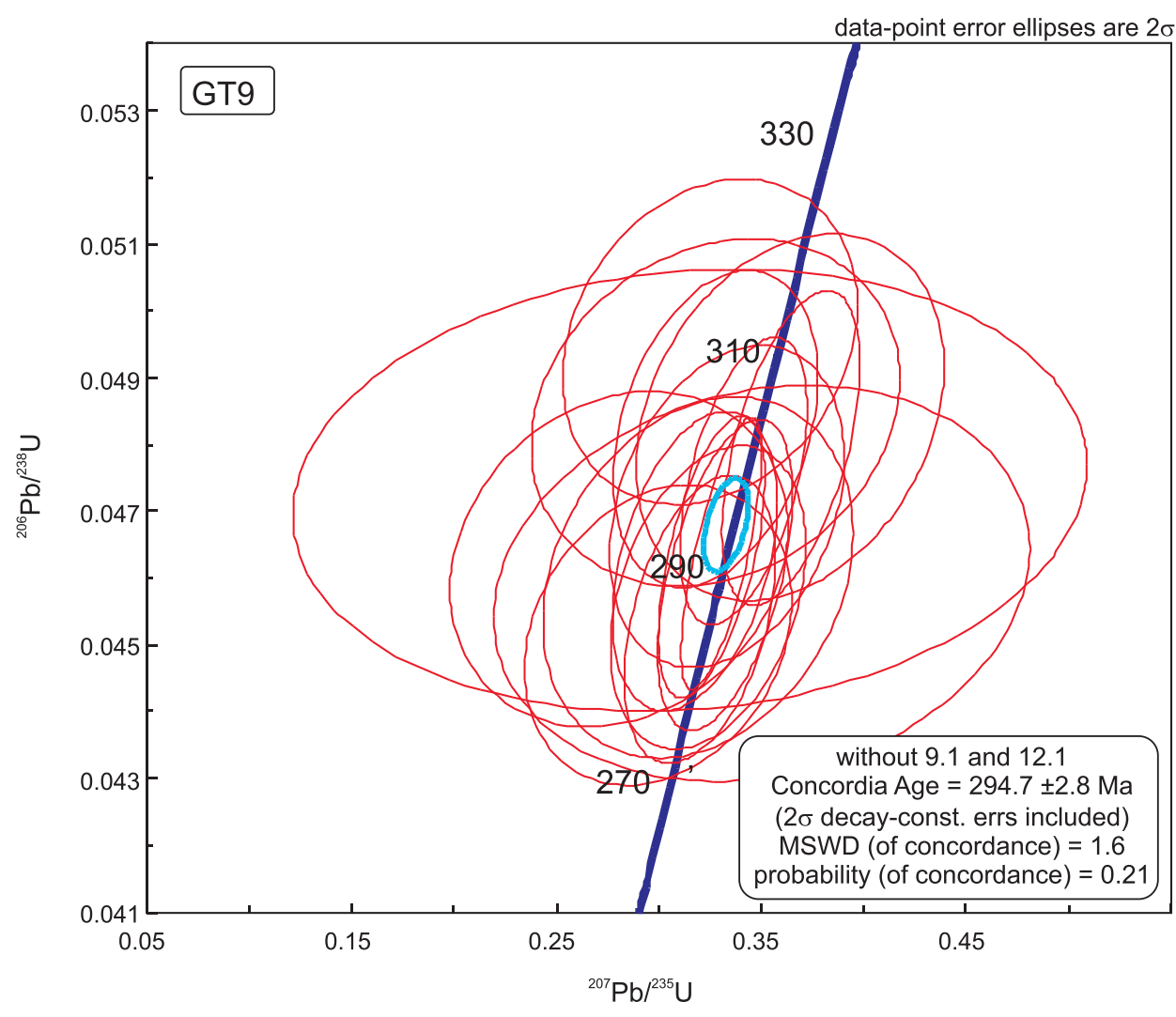

Fig. 6. Concordia diagram showing results of SHRIMP zircon analyses from tonalite GT9

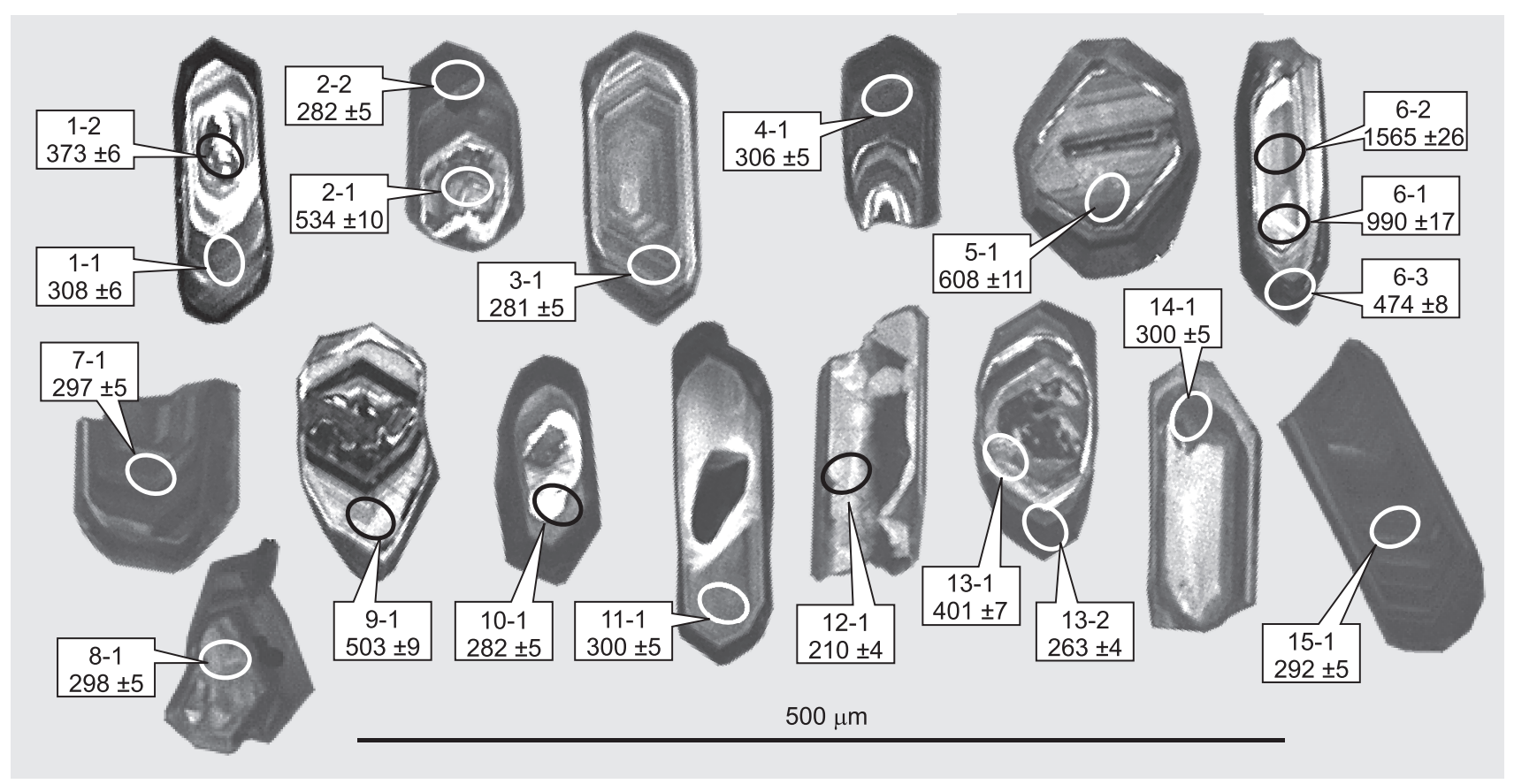

Fig. 7. Cathodoluminescence images of zircons analysed from Bt-Ms granite 210

Symbols of analytical points correspond to those in Table $3 ;{ }^{206} \mathrm{~Pb} /{ }^{238} \mathrm{U}$ ages and one $-\sigma$ errors (rounded to integers) are given 


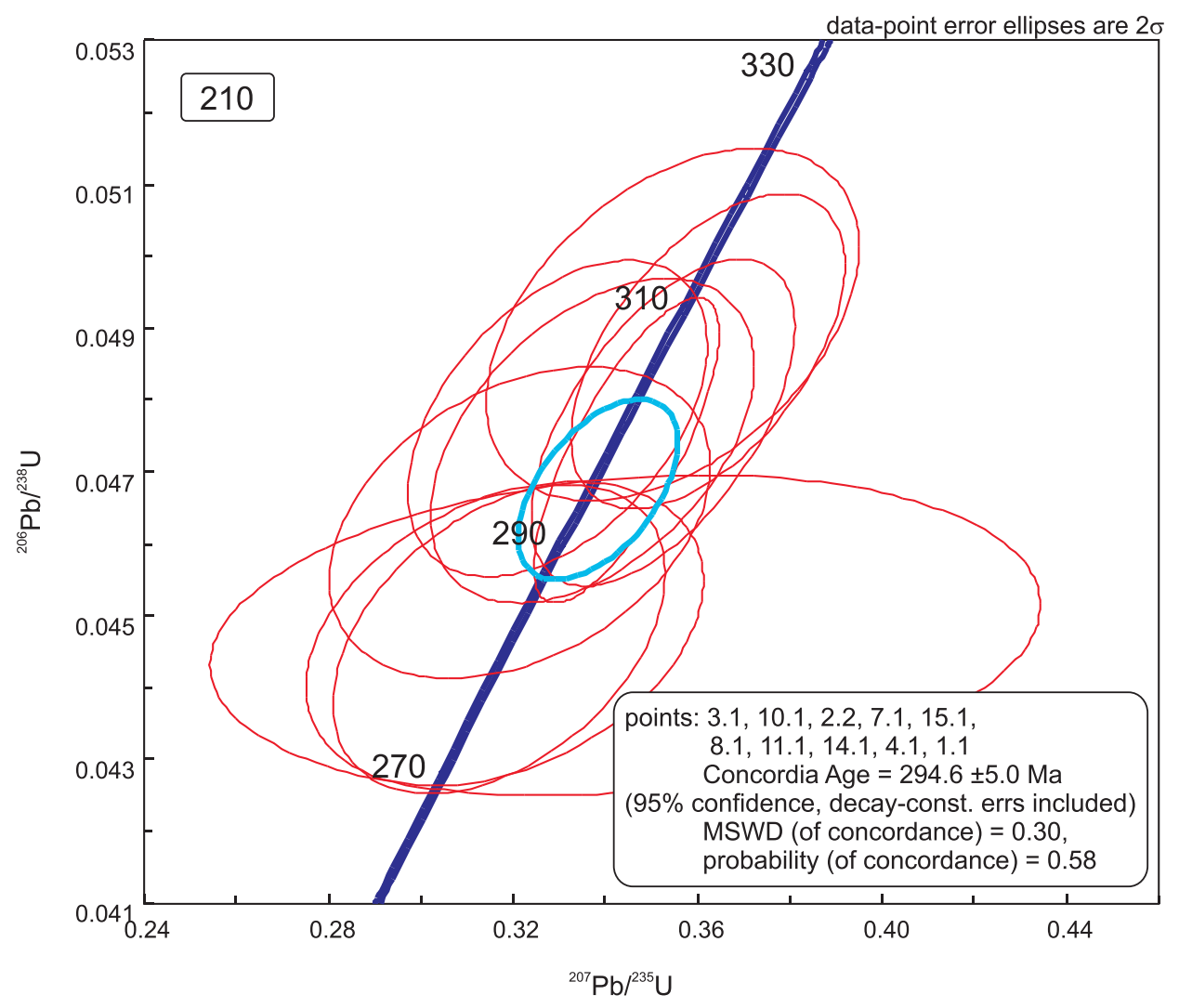

Fig. 8. Concordia diagram showing results of SHRIMP zircon analyses from biotite-muscovite granite $\mathbf{2 1 0}$

$474 \pm 9$ Ma old (the latter two ${ }^{206} \mathrm{~Pb} /{ }^{238} \mathrm{U}$ ages). Having in mind this strong age zonation, the ages obtained in this grain may

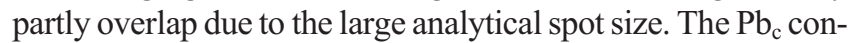
tents in these points are low $(0.07-0.12 \%)$, whereas the ${ }^{232} \mathrm{Th} /{ }^{238} \mathrm{U}$ ratio drops from 0.57 in the core to 0.04 in the rim. Relatively old (compared with the main group 2) and generally concordant ages were found in five other points: 5.1 (608 $\pm 11 \mathrm{Ma}), 2.1(534 \pm 10 \mathrm{Ma}), 9.1(503 \pm 9 \mathrm{Ma}), 13.1(401 \pm 7 \mathrm{Ma})$ and $1.2(374 \pm 7 \mathrm{Ma})$. They all represent grain interiors. Two of them have high $\mathrm{Pb}_{\mathrm{c}}$ values $(2.1-1.36 \%, 13.1-2.48 \%)$, and most of them have low ${ }^{232} \mathrm{Th} /{ }^{238} \mathrm{U}$ ratios $(0.03-0.16$; Table 3$)$.

Ten analytical points $(1.1,2.2,3.1,4.1,7.1,8.1,10.1,11.1$, 14.1 and 15.1) form the main age group of zircons, with a concordant age of $295 \pm 5 \mathrm{Ma}$ (Fig. 8). These points represent both internal parts (mantles) and outer rims of grains. Most of them are CL-dark and have varied but predominantly moderate ${ }^{232} \mathrm{Th} /{ }^{238} \mathrm{U}$ ratios $(0.07-1.06)$. However, three analytical points seem to be distinctly younger, with ${ }^{206} \mathrm{~Pb} /{ }^{238} \mathrm{U}$ dates around $282 \mathrm{Ma}$, though based on a small number of points; it is difficult to decide whether these are geologically significant ages or rather artefacts caused, e.g., by radiogenic $\mathrm{Pb}$ loss. One of these points (2.2) displays high $\mathrm{Pb}_{\mathrm{c}}(7.39 \%)$, similarly to two other points $(12.1=6.78$, and $13.2=4.36 \%)$ that yielded unrealistically young dates of $c a .210$ and $263 \mathrm{Ma}$, respectively. These results suggest a possible disturbance of the U-Pb system after the magmatic crystallisation of the granite.

Overall, the twenty points analysed in sample 210 have revealed a wide diversity of ages, including a wide range of inheritance and a fairly coherent magmatic population. The abundant inherited zircons, varying in age from $c a .374 \mathrm{Ma}$ to $c a .1 .5 \mathrm{Ga}$, represent crustal components of various ages, from Mesoproterozoic to mid-Paleozoic. The magmatic zircon growth of the main population is fairly well-constrained at $295 \pm 5 \mathrm{Ma}$.

\section{DISCUSSION}

The SHRIMP zircon study has shown that the Gęsiniec intrusives, represented by the medium-grained tonalite (GT9) and the Bt-Ms granite (210) in dykes cutting the tonalite, are of the same age of $295 \mathrm{Ma}$. The same Rb-Sr age (294.8 $\pm 0.6 \mathrm{Ma})$ was obtained earlier by Pietranik and Waight (2008) from a WR+biotite+plagioclase isochron for the leucocratic medium-grained quartz diorite Gęsiniec tonalite.

The sharp contacts between the tonalite and the Bt-Ms granite dykes indicate that the emplacement of the granite took place when the tonalite was completely solidified. After the emplacement, some the Bt-Ms granite dykes, associated with 
the granodiorite, were deformed - bent or torn (Fig. 3). Apparently, the presence of the (still hot?) granodiorite near the veins facilitated their bending and healing of the cracks. These field relationships suggest that the emplacement of the tonalite, granodiorite and Bt-Ms granite magmas took place over a short time spam, shorter than the errors of the SHRIMP zircon ages.

Although the zircons from the tonalite and Bt-Ms granite show the same age, they differ considerably in their physical and chemical features. The zircon population in the tonalite is homogeneous and the grains are relatively large and euhedral. They show strong CL zonation which is not reflected in age variation. In contrast, the zircon grains in the Bt-Ms granite are much smaller than those in the tonalite, and have various morphologies. Most of them are euhedral, with a distinct internal recurrent zonation. A number of grains have inherited cores with ages from $c a .374 \mathrm{Ma}$ to $c a$. $1.5 \mathrm{Ga}$. The age spectrum of the inherited zircons is fairly similar to the ages reported from orthogneisses of the Strzelin Massif (Oberc-Dziedzic et al., 2003a; Klimas, 2008). They may represent a crustal component of the Bt-Ms granite magma and indicate that similar gneisses could have been the source material for this magma. They also suggest that the magmatic protolith of the orthogneisses and that the magma of the Bt-Ms granite could have come from similar sources or that the magma of the Bt-Ms granite was contaminated by the gneisses.

The $295 \pm 3$ Ma age of the Gęsiniec tonalite is the same as the age obtained previously for the Kalinka tonalite from the southern part of the Strzelin Massif (Oberc-Dziedzic et al., 2010). Both the tonalites show a similar geochemical composition (Białek and Pietranik, 2006). However, the Kalinka tonalite is more homogeneous than the Gessiniec tonalite. Moreover, the Kalinka tonalite is, like most of the tonalites from the southern part of the Strzelin Massif, fine-grained, whereas the Gęsiniec tonalite is medium-grained. The fine grain-size in the Kalinka tonalite indicates a faster rate of its crystallisation, compared with the Gęsiniec tonalite. This seems to be supported by the zircon habits: the zircon crystals from the Kalinka tonalite are long-prismatic, pencil-like (ObercDziedzic et al., 2010), typical of fast crystallisation, whereas the zircons from the Gęsiniec tonalite are mostly short- and, subordinately, normal-prismatic. In spite of the local differences, the tonalities from different parts of the Strzelin Massif represent the same, $c a$. $295 \mathrm{Ma}$ plutonic event recorded in the eastern part of the Fore-Sudetic Block.

\section{CONCLUSIONS}

1. The Gęsiniec composite intrusion was formed in the course of three late Variscan magmatic episodes at $295 \mathrm{Ma}$, which occurred shortly one after another in the following sequence: tonalite, granodiorite and granite.

2. The Bt-Ms granite contains inherited zircons varying in age from $c a .374 \mathrm{Ma}$ to $c a .1 .5 \mathrm{Ga}$, similar to zircon ages from the surrounding orthogneisses, which could be, thus, the source of the granite magma or its contaminant.

3. The age of the Gesiniec tonalite is the same as the Kalinka tonalite in the southern part of the Strzelin Massif, and both represent the late-stage granitoid plutonism event in the Variscides of the NE margin of the Bohemian Massif.

Acknowledgements. The study was supported by internal grants 1017/S/ING and 2022/W/ING of the University of Wrocław. K. Dymna helped greatly in zircon separation. S. Sergeev and other colleagues of VSEGEI are thanked for their assistance with SHRIMP analysis. We are also grateful to M. Kohút and an anonymous reviewer for their constructive comments that helped to improve this paper.

\section{REFERENCES}

BADURA J. (1979) - Szczegółowa mapa geologiczna Sudetów, ark. Stolec 1:25000. Inst. Geol., Wyd. Geol., Warszawa.

BEDERKE E. (1931) - Die moldanubische Überschiebung im Sudetenvorlände. Zentralblatt für Mineral. Geol. Paläont. Abt. B: 349-408.

BIAŁEK J. and PIETRANIK A. (2006) - Geochemistry and petrology of tonalite and granodiorite from Strzelin Crystalline Massif - comparison. Miner. Pol., Spec. Pap., 29: 103-106.

BLACK L. P., KAMO S. L., ALLEN C. M., ALEINIKOFF J. N., DAVIS D. W., KORSCH R. J. and FOUDOULIS C. (2003) - TEMORA 1: a new zircon standard for Phanerozoic U-Pb geochronology. Chem. Geol., 200: $155-170$.

BOREK Z. (1987) - Kompleksowa dokumentacja geologiczna złóż granitoidów „Strzeliński Okręg Eksploatacji Surowców Skalnych”. Arch. Przedsiębiorstwa Geologicznego Proxima we Wrocławiu.

CHLUPAČ I. (1975) - New finds of fauna in the metamorphic Devonian of the Hruby Jeseník Mts. (Moravia, Czechoslovakia) (in Czech with English summary). Čas. Miner. Geol., 20: 259-268.

DUDEK A. (1980) - The crystalline basement block of the outer Carpathians in Moravia-Bruno-Vistulicum. Rozpravy Československé Akademie Véd, Ǩada matematických a přirodnich Véd, 90: 1-85.
FINGER F., FRASL G., HÖCK V. and STEYRER H. P. (1989) - The granitoids of the Moravian Zone of northeast Austria: products of a Cadomian active continental margin? Precambrian Res., 45: 235-245.

FINGER F., ROBERTS M. P., HAUNSCHMID B., SCHERMAIER A. and STEYRER H. P. (1997) - Variscan granitoids of central Europe: their typology, potential sources and tectonothermal relations. Miner. Petrol., 61: 67-96.

KLIMAS K. (2008) - Geochronology and petrogenetical study of zircons from selected crystalline rocks in the eastern part of the Fore-Sudetic Block (in Polish with English summary). Uniwersytet Wrocławski, Inst. Nauk Geol., Wrocław.

KRÖNER A. and MAZUR S. (2003) - Proterozoic and Palaeozoic crustal components across the East/Central Sudetes boundary at the eastern margin of the Bohemian Massif: new $\mathrm{U} / \mathrm{Pb}$ single zircon ages from the eastern Fore-Sudetic block (SW Poland). J. Czech Geol. Soc. Abstract Vol., 48 (1-2): 83-84.

LARIONOV A. N., ANDREICHEV V. A. and GEE D. G. (2004) - The Vendian alkaline igneous suite of northern Timan: on microprobe $\mathrm{U}-\mathrm{Pb}$ zircon ages of gabbros and syenite. Geol. Soc. London Mem., 30: 69-74. 
LUDWIG K. R. (2005a) - SQUID 1.12 A User's Manual. A Geochronological Toolkit for Microsoft Excel. Berkeley Geochronol. Center Spec. Publ.: 1-22, http://www.bgc.org/klprogrammenu.html

LUDWIG K. R. (2005b) - User's Manual for ISOPLOT/Ex 3.22. A Geochronological Toolkit for Microsoft Excel. Berkeley Geochronol. Center Spec. Publ.: 1-71, http://www.bgc.org/klprogrammenu.html

MAZUR S., ALEKSANDROWSKI P., KRYZA R. and OBERC-DZIEDZIC T. (2006) - The Variscan Orogen in Poland. Geol Quart., 50 (1): 89-118

MAZUR S., ALEKSANDROWSKI P., TURNIAL K. and AWDANKIEWICZ M. (2007) - Geology, tectonic evolution and Late Palaeozoic magmatism of Sudetes - an overview. In: Granitoids in Poland (eds. A. Kozłowski and J. Wiszniewska). AM Monograph, 1: 217-229.

MAZUR S., KRÖNER A., SZCZEPAŃSKI J., TURNIAK K., HANŽL P., MELICHAR R., RODIONOV N. V., PADERIN I. and SERGEEV S. A. (2010) - Single zircon U-Pb ages and geochemistry of granitoid gneisses from SW Poland: evidence for an Avalonian affinity of the Brunian microcontinent. Geol. Mag., 147 (4): 508-526.

OBERC J. (1966) - Geology of crystalline rocks of the Wzgórza Strzelińskie Hills, Lower Silesia (in Polish with English summary). Stud. Geol. Pol., 20: 1-187.

OBERC J., OBERC-DZIEDZIC T. and KLIMAS-AUGUST K. (1988) Mapa geologiczna Wzgórz Strzelińskich w skali 1:25 000 (ed. J. Oberc). Inst. Nauk Geol. Uniwersytetu Wrocławskiego, Przedsiębiorstwo Geologiczne Wrocław.

OBERC-DZIEDZIC T. (1999) - Geology of the Strzelin granitoids (Fore-Sudetic Block, SW Poland). Miner. Soc. Pol., Spec. Pap., 13: $22-32$.

OBERC-DZIEDZIC T. (2007) - Internal structure of the granite and tonalite intrusions in the Strzelin massif. In: Granitoids in Poland (eds. A. Kozłowski and J. Wiszniewska). AM Monograph, 1: 217-229.

OBERC-DZIEDZIC T. and MADEJ S. (2002) - The Variscan overthrust of the Lower Palaeozoic gneiss unit on the Cadomian basement in the Strzelin and Lipowe Hills massifs, Fore-Sudetic Block, SW Poland; is this part of the East-West Sudetes boundary? Geol. Sudet., 34: 39-58.

OBERC-DZIEDZIC T. and PIN C. (2000) - The granitoids of the Lipowe Hills (Fore-Sudetic Block) and their relationship to the Strzelin granites. Geol. Sudet., 33: 17-22.

OBERC-DZIEDZIC T., PIN C., DUTHOU J. L. and COUTURIE J. P. (1996) - Age and origin of the Strzelin granitoids (Fore-Sudetic Block, Poland): ${ }^{87} \mathrm{Rb} /{ }^{86} \mathrm{Sr}$ data. N. Jb. Miner. Abh., 171: 187-198.

OBERC-DZIEDZIC T., KLIMAS K., KRYZA R. and FANNING M. C. (2003a) - SHRIMP U-Pb zircon geochronology of the Strzelin gneiss, SW Poland: evidence for a Neoproterozoic thermal event in the Fore-Sudetic Block, Central European Variscides. Int. J. Earth Sc. (Geol. Rundsch.), 92: 701-711.

OBERC-DZIEDZIC T., KLIMAS K., KRYZA R., FANNING M. C. and MADEJ S. $(2003 b)$ - SHRIMP zircon ages from gneiss help locate the West-East Sudetes boundary (NE Bohemian Massif, SW Poland). J. Czech Geol. Soc. Abstr., 48 (1-2): 98.
OBERC-DZIEDZIC T., KRYZA R., KLIMAS K., FANNING M. C. and MADEJ S. (2005) - Gneiss protolith ages and tectonic boundaries in the NE part of the Bohemian Massif (Fore-Sudetic Block, SW Poland). Geol. Quart., 49 (4): 363-378.

OBERC-DZIEDZIC T., KRYZA R. and BIAŁEK J. (2010) - Variscan multistage granitoid magmatism in Brunovistulicum: petrological and SHRIMP U-Pb zircon geochronological evidence from the southern part of the Strzelin Massif, SW Poland. Geol. Quart., 54 (3): 301-324.

OLIVER G. J. H., CORFU F. and KROUGH T. E. (1993) - U-Pb ages from SW Poland: evidence for a Caledonian suture zone between Baltica and Gondwana. J. Geol. Soc. Lond., 150: 355-369.

PIETRANIK A. and KOEPKE J. (2009) - Interactions between dioritic and granodioritic magmas in mingling zones: plagioclase record of mixing, mingling and subsolidus interactions in the Gęsiniec Intrusion, NE Bohemian Massif, SW Poland. Contrib. Miner. Petrol., 158: $17-36$.

PIETRANIK A. and WAIGHT T. (2008) - Processes and sources during Late Variscan dioritic-tonalitic magmatism: insights from plagioclase chemistry (Gęsiniec Intrusion, NE Bohemian Massif, Poland). J. Petrol., 49 (9): 1619-1645.

PIETRANIK A., KOEPKE J. and PUZIEWICZ J. (2006) - Crystallization and resorbtion in plutonic plagioclase: implications on the evolution of granodiorite magma (Gęsiniec granodiorite, Strzelin Crystalline Massif, SW Poland). Lithos, 86: 260-280.

PUZIEWICZ J. and OBERC-DZIEDZIC T. (1995) - Age and origin of granitoids of the Fore-Sudetic block (in Polish with English summary). Ann. Soc. Geol. Pol. Spec. Vol., Przewodnik LXVI Zjazdu PTG: 273-284

SCHALTEGGER U. (1997) - Magma pulses in the Central Variscan Belt: episodic melt generation and emplacement during lithospheric thinning. Terra Nova, 9: 242-245.

STACEY J. S. and KRAMERS J. D. (1975) - Approximation of terrestrial lead isotope evolution by a two-stage model. Earth Planet. Sc. Lett., 26: $207-221$

STEIGER R. H. and JÄGER E. (1977) - Subcommission on geochronology: convention on the use of decay constants in geo- and cosmochronology. Earth Planet. Sc. Lett., 36: 359-362.

TURNIAK K., TICHOMIROVA M. and BOMBACH K. (2006) - Pb-evaporation zircon ages of post-tectonic granitoids from the Strzelin Massif (SW Poland). Miner. Soc. Pol., Spec. Pap., 29: 212-215.

WIEDENBECK M., ALLÉ P., CORFU F., GRIFFIN W. L., MEIER M., OBERLI F., von QUADT A., RODDICK J. C. and SPIEGEL W. (1995) - Three natural zircon standards for U-Th-Pb, Lu-Hf, trace element and REE analyses. Geostandards Newslett., 19: 1-23

WILLIAMS I. S. (1998) - U-Th-Pb geochronology by ion microprobe. Rev. Econom. Geol., 7: 1-35.

WÓJCIK L. (1968) - Szczegółowa mapa geologiczna Sudetów, ark. Ciepłowody 1:25 000. Inst. Geol., Wyd. Geol., Warszawa.

WROŃSKI J. (1973) - Szczegółowa mapa geologiczna Sudetów, ark. Ziębice 1:25 000. Inst. Geol., Wyd. Geol., Warszawa. 